Research Council. In part II of his Report Dr. Keyston gives an outline of the constitution and functions of such a Research Council. He suggests that the Council should be a corporate body set up by legislation and, while it should be responsible to the Governments of the territories and receive a capital endowment as well as annual votes, it should be empowered to receive donations from other sources, to appoint its own Executive Committee, specialist committees, and research staff, and that at least half its members should be unofficial. Part III is devoted to a survey of research requirements of the Rhodesias and Nyasaland in which joint action can be recommended. This section is concerned mainly with such topics as agricultural, geological, hydrological, medical, and veterinary researches, but also includes proposals for sociological and anthropological research, which, it is suggested, should be built up around the Rhodes-Livingstone Institute, with the proviso, however, that the headquarters of the Institute should be moved to Salisbury. An interesting suggestion is made that sociological research should be linked up with Development Centres such as those established in Northern Rhodesia as part of the ten-year development plan; a further suggestion envisages the formation of a Central African Sociological Research Centre, by means of which 'sociologists . . . can be attached for short or long periods to any department of Government, any investigational team, any private industry, any activity in which the African becomes deeply involved'. 'Sociology', concludes Dr. Keyston, 'pervades the applicational end of all plans for progress and development in Central Africa. One cannot define crisply what the sociologist will contribute to the application of new knowledge and legislation ... but we can be sure that without the expert we shall have more difficulty than we need.'.

\title{
The Human Geography of Inter-tropical Africa
}

A Research Committee of the British Association for the Advancement of Science was established in 1926 to encourage the study of the human geography of inter-tropical Africa. At that time there were few trained geographers in Africa, and the Committee was mostly concerned with the collection of information from government officers, anthropologists, missionaries, and others. A pamphlet, 'The human geography of inter-tropical Africa', was prepared and was widely circulated. Special attention was drawn to the questionnaire contained in it, and the response was very good from some territories, notably from Northern Rhodesia. Professor A. G. Ogilvie, then Secretary of the Committee, devoted the bulk of his presidential address to Section E (Geography) of the British Association in 1934 to an analysis of the human geography of Northern Rhodesia on the basis of the replies received to the questionnaire (also published in the Scottish Geographical Magazine, so (1934), pages $353-78$ ).

At the Newcastle-upon-Tyne meeting of the British Association in 1949 the Committee was reconstituted under the chairmanship of Professor Ogilvie, with R. W. Steel as Secretary. The other members are Professors Frank Debenham and Daryll Forde, Dr. R. J. Harrison Church, and Mr. D. B. Mather. The Committee believes that there is room for some co-ordination between those who are interested in the human geography of Africa, whether they are resident in the tropics or in the United Kingdom; and it hopes that more progress may be possible than in the period before the war, especially because of the establishment of departments of geography at Makerere and Ibadan, and in the University College of the Gold Coast, and of institutions such as the Rhodes-Livingstone Institute in Northern Rhodesia. Moreover, many more anthropologists are now at work in the field and are concerned to record material on the significance of the physical environment. Great progress has also been made in the topographical mapping of the colonies during recent years.

As a first step the Committee is anxious to make contact with all persons in tropical 
Africa who are interested in the geographical study of the districts where they live and work. Many names have already been received through Departments of Geography in Great Britain, and copies of the pamphlet referred to above have been dispatched to them. Anyone who feels able to help the Committee in its work, or who thinks that the Committee may be able to assist him-for example, by recommending the publication of a paper in one of the geographical periodicals - is invited to write to the Secretary, at the School of Geography, Mansfield Road, Oxford, England.

R. W. STEEL

\section{Nigerian Festival of the Arts}

THE first Nigerian Festival of the Arts, held in Lagos, was opened by the Governor, Sir John Macpherson, on 23 April and closed with a concert at the Glover Memorial Hall on 27 April 1950.

The function of the Nigerian Festival of the Arts, which it is hoped will be an annual event, has been described by Mr. John Stocker, first Chairman of the Festival Committee. 'In Nigeria', he writes, 'there are a few well-known artists, hundreds of musicians, and thousands of craftsmen and dancers. Their art has been part of the life of the country for generations, they are part of its traditions, but they may die out unless they are encouraged and supported now. To win this encouragement and support, the arts must be given publicity and kept before the public eye.'

Plans for the Festival originated with a meeting of nearly roo interested Europeans and Africans called together by Mr. R. J. Parkhouse, former British Council representative in Nigeria, and Father McCarthy of the Catholic Mission.

The competitive events in the Festival covered many branches of Arts and Crafts. For instance, in the Literature Section, there were awards for original poems in English and in an African language, and for short stories, one-act plays, and essays. Competitive events were held in the different branches of music, drama, and dancing. In the Art Section events included drawing and painting from life and from imagination. There was a large Crafts Section which covered carpentry and joinery, carving, leatherwork, iron and tinplate, beaten brassware, jewellery, textiles, pottery, and other crafts.

Entries for the Festival awards numbered over 600, of which a large proportion were submitted from the more outlying parts of the Territory. Nine silver challenge cups, five of which had been presented by Africans, were awarded for outstanding entries in the various sections, while shields and silver and bronze medals were also awarded.

\section{Théâtre Africain en A.E.F.}

Au Cercle Culturel de Poto-Poto (Moyen-Congo), une section théâtrale est créée, et M. Bandila en a été élu Président. La troupe d'Antoine Ahoudji qui participe à cette activité nouvelle est déjà bien connue. Son Directeur et ses acteurs, presque tous originaires d'A.O.F., font revivre les vieilles légendes de leur pays, ou improvisent sur l'actualité du village, avec un sens de l'observation et un naturel qui les assimilent à des comédiens de métier.

Le Président du Cercle Culturel de Poto-Poto, M. Galingui, a demandé à de très jeunes gens de composer et 'monter' une pièce d'après un conte (souvenir scolaire) pris dans le célèbre 'Mamadou et Binetta'. Par ailleurs, des auteurs se révèlent. Certains sont tentés par les problèmes qu'amène l'évolution; d'autres puisent leurs sujets dans les 'faits divers' du village ou dans les souvenirs d'une enfance en brousse. Ces derniers rédigent des pièces qui laissent une large part à la danse et à la musique, toujours si étroitement mêlées aux événements de la vie africaine. Le Service d'Action Sociale se propose de publier et récompenser les meilleurs ouvrages. Un peintre africain réalise les décors qui nous transporteront où le voudra la fantaisie des auteurs. 